Arhe XVIII, 35/2021

UDK 159.955.4 Bourdieu P.

DOI https://doi.org/10.19090/arhe.2021.35.261-277

Originalni naučni rad

Original Scientific Article

VEDRAN DIZDAREVIĆ 1

Univerzitet „Sv. Kiril i Metodij“ u Skoplju, Filološki fakultet „Blaže

Koneski“, Severna Makedonija

\title{
ANALIZA KONCEPTA REFLEKSIVNOSTI U TEORIJI PJERA BURDJEA
}

Sažetak: U ovom radu ćemo analizirati jedan od centralnih pojmova u teoriji francuskog sociologa i antropologa Pjera Burdjea, pojam refleksivnost. U prvom djelu, predstavljamo ovaj pojam i široku tradiciju kantijanskog filozofskog projekta, te specifično čitanje ovog projekta od strane Burdjea, kroz prizmu Emila Dirkema, Marsela Mosa, Rudolfa Karnapa i Ludviga Vitgenštajna. Nakon toga, preko detaljnog čitanja nekoliko tekstova Burdjea uz analizu njegovih komentatora, definisaćemo pojam refleksivnost i njegovo značenje. U drugom djelu, razmotrićemo konkretni problem naučnika u polju nauke, njegov odnos prema polju, njegovom habitusu i specifični problem sholastičke situacije - glavne prepreke procesa refleksivnosti - odnosno praktikovaćemo refleksivnost na sami poziv nauke i profesije naučnika. Takođe, ilustrovaćemo šta tačno znači pričati o naučnom polju ili polju nauke, a ne samo o nauci po sebi. U trećem djelu, usmerenost će nam biti na potrebi za refleksivnost u domenu društvenih nauka, koje su istovremeno i proizvod i proizvođač društvene stvarnosti.

Ključne reči: refleksivnost, Pjer Burdje, Imanuel Kant, polje, polje nauke, habitus, sholastička iluzija, društvene nauke

\section{UVOD}

Refleksivnost je pojam sa kojim moraju da se susretnu svi koji se bave i koriste teoretskim aparatom francuskog sociologa Pjera Burdjea. Jedna istraživačica njegovih teorija navodi da je refleksivnost u jezgru Burdjeovog djela, započevši od njegove prve knjige posvećene Alžiru

\footnotetext{
${ }^{1}$ E-mail adresa autora: vdizdarevic@yahoo.com
} 
krajem šezdesetih godina $\mathrm{XX}$ vjeka, gdje je refleksivnost implicitno upotrebljena, pa sve do njegovih posljednjih djela u novom milenijumu, $u$ kojima se Burdje eksplicitno zanima njome i postavlja je u centar njegove kritičke sociologije. (Deer 2008, 199-200) No, šta tačno znači refleksivnost? Kako možemo da je prepoznamo? Zašto je potrebna, koje su dobrobiti ako se sa njom koristimo i konačno, kako možemo da je upotrebimo u našem istraživačkom radu? Refleksivnost u teoriji Burdjea suštinski je povezana sa sholastičkom iluzijom pod koju često potpadaju učenjaci, istraživači i svi koji se bave naukom. Istraživači koji nisu refleksivni u odnosu na svoj posao vjeruju da se bave čistom naukom, van pritisaka i interesa svakodnevne stvarnosti (ekonomske stvarnosti najviše od svih), a najčešče ne mogu da zapaze kakve posljedice može da ima njihov istraživački rad prilikom konstruiranja i legitimiranja stvarnosti koju proučavaju. U ovom ćemo radu na početku definirati refleksivnost kao ključno metodološko sredstvo u djelima Pjera Burdjea, nakon toga ćemo se baviti naučnim poljem i sholastičkom iluzijom, što onemogućava nauku da se nadgleda kao svako drugo polje i što ne dozvoljava da se otkriju specifičnosti njenog funkcioniranja i djelovanja na agente koji ga naseljavaju. Na kraju, u trećem poglavlju, obratit ćemo pažnju na potrebu da društvene nauke budu refleksivne.

\section{2. ŠTA JE TO REFLEKSIVNOST?}

Kada se Džon Lok, u Ogledu o ljudskom razumu, pita kako i odakle dolaze ideje u našem umu, nalazi dva izvora: senzacije i refleksije. Nasuprot senzacijama, sa kojima ideje dobijamo iskustvom koje čula sabiraju od vanjskog svjeta, drugi izvor koji nas posebno interesuje, predstavlja „percepcija operâcija našeg vlastitog uma unutar u nama“. (Locke 2014; 95 96) Znači, refleksija, u osnovnom smislu riječi, predstavlja okrenutost prema sopstvenom umu, odnosno prema idejama našeg sopstvenog uma. Lok kao jedan od najpoznatijih empirista, refleksiji daje sekundarnu ulogu, podređenu senzaciji, iz jednostavnog razloga što jedini izvor ideja jeste iskustvo, odnosno vanjski svjet. Burdje, za razliku od Loka i drugih 
empirista, refleksiju razumije i definira na suštinski drugačiji način, što je posebno važno, zato što naivni realizam ${ }^{2}$ koji proizilazi iz argumenata empirista, još uvijek jeste kamen temeljac i osnova naučnog razmišljanja. Tako, nećemo ga razumjeti ako ga smjestimo u filozofsko-naučnu tradiciju empirizma i naivnog realizma.

Burdje pronalazi korjene refleksivnosti (kao što je on definira) u kantijanskom kritičkom projektu, utemeljenom u Kritici čistoga uma, u istraživanju preduslova svakog mogućeg iskustva i preko otkrivanja apriornih formi čula i razuma (transcendentalna estetika i transcendentalna analitika) koje prethode svakom mogućem čulnom iskustvu, a preduslovi za to iskustvo se nalaze u samom subjektu, a ne u svijetu. ${ }^{3}$ Ipak Burdje se nadovezuje na kantijansku tradiciju sa jednom ključnom razlikom; on je čita ili promišlja iz vizure sociologije Emila Dirkema: „na mjesto Kantovih univerzalnih apriornih preduslova“, piše on, ,ja postavljam društveno konstruirane a priori preduslove, kao što je to napravio Dirkem za religijske principe klasifikacije i konstrukcije svetog u osnovnim formama religijskog života i njegovom djelu za Primitivne forme klasifikacije“. (Burdije

2 Po Rejmondu Vilijamsu, ,pretpostavka naivnog realizma” podrazumjeva „da se stvari gledaju onakve kakve jesu, nezavisno od naših reakcija na njih". U prvom poglavlju Duge revolucije, on bilježi da je ova teorija percepcije neodrživa a razlog jeste to što je svaka percepcija intrinzično kreativan interpretativan akt i da je ,cijelo ljudsko iskustvo interpretacija neljudske stvarnosti““. (Williams 1961:36)

${ }^{3} \mathrm{U}$ jednom od rijetkih slikovitih i konkretnih poglavlja Kritike čistoga uma Kant daje sledeću ilustraciju transcendentalnog projekta preko slike ,teritorije čistoga razuma“: ,,.. ovo zemljište jeste jedno ostrvo koje je sama priroda zatvorila u nepromenjlive granice. To je postojbina istine (jedno dražesno ime) koju opkoljava jedan prostrani i burni okean, pravo sedište privida, gde poneka magluština i poneka santa leda koja će se ubrzo rasplinuti lažno nagoveštavaju nove zemlje i, zavaravajći praznim nadama mornara koji neprestance izgleda za novim otkrićima, zapliću ga $u$ pustolovine od kojih nikako ne može da odustane, a koje isto tako nikako ne može da privede kraju. Ali pre nego se usudimo na ovo more, da bismo ga ispitali u svim pravcima i da bismo se uverili da li se imamo nečemu otuda nadati, biće korisno da bacimo još jedan pogled na kartu zemljišta koje upravo hoćemo da napustimo i da se pitamo prvo: zar ne bismo mogli, ili bar po nuždi morali u svakom slučaju biti zadovoljni sa onim šta ovo zemljište u sebe sadrži, ako inače nema nigde nikakvog zemljišta na kome bismo se mogli nastaniti; drugo: s kakvim pravom držimo mi ovo zemljište i možemo li se na njemu sigurno učvrstiti protiv svih neprijateljskih namera." (Kant 2012: 211) 
2004:78) Apriorne kategorije, prema Burdjeu, ne nalaze se u izoliranom subjektu koji konstituira svijet shodno tim kategorijama, već se njihov izvor nalazi u društvu u kojem se jedinka rađa, razmišlja i djeluje; takođe oni su proizvod određenih istorijskih okolnosti, vješto i detaljno skiciranih od Ernesta Kasirera u Filozofiji prosvjetiteljstva, i samim tim ne mogu se posmatrati sub specie aeternitatis. (Cassirer 1951) Osim u pravcu „sociologiziranog“ i ,istoriziranog“ Kanta, Burdje nas upućuje na uticaj Rudolfa Karnapa i njegovog poznatog djela Empirizam, semantika $i$ ontologija, u kojem njemački fillozof pravi distinkciju između unutrašnjih i vanjskih pitanja koja mogu da se postave o funkcioniranju jednog naučnog sistema. ${ }^{4}$ Ako započnemo od Kantove transcendentalne filozofije, preko spomenutog Karnapovog teksta, do Strukture naučnih revolucija Tomasa Kuna (Kun 1974), postoji logična linija razvoja prema progresivnoj, relativiziranoj verziji racionalnosti, jer ovi mislioci, slično kao i Dirkem, istoriziraju $\mathrm{i}$ sociologiziraju univerzalne $\mathrm{i}$ transtemporalne kategorije kantijanskog subjekta. (2003:80) Na kraju, tu je filozofija kasnog Vitgenštajna, pročitana iz sociološke prizme Dejvida Blora (Bloor 1983) i totalni fakt Marsela Mosa, koncept koji u suštini sadrži veliki dio toga što Burdje naziva refleksivnost. ${ }^{5}$

\footnotetext{
${ }^{4}$ U spomenutom tekstu Karnap govori da je ,koncept realnosti koji se javlja u ovim unutrašnjim pitanjima empirijski, naučni, ne-metafizički koncept. Da se prepozna nešto kao nešto realno ili kao realan događaj znači da se uspije da se inkorporira u sistem stvari u partikularnoj vreme-prostor poziciji tako što će se podudarati zajedno sa svim realnim stvarima, u saglasnosti sa pravilima konstrukcije". Vanjska pitanja odbacuju se kao pseudo, neteoretska pitanja kamuflirana da liče ne teoretska pitanja, bez ikakve kognitivne sadržine. Ona ne ulaze ni u domen nauke ni u domen filozofije; to su praktična pitanja, a praktična pitanja treba da se mjere iz pragmatičnog aspekta, na osnovi toga koliko su ekspidientni (orijentirani prema novim ciljevima) ili plodni, odnosno koliko pomažu nauci da ona ide naprijed. (Carnap 1950:3-9) Može se reći da je Burdje kao temelj svoje teorije refleksivnosti iskoristio upravo pitanja koja Karnap odbacuje kao praktična i nefilozofska i proučava ih kroz više perspektiva, ali najviše kroz prizmu sociologije.

5 U Uvodu za djelo Marsela Mosa Levi-Stros primjećuje da „svaka validna interpretacija mora da spoji istorijske ili komparativne analize i subjektivnost proživljenog iskustva”, a dalje dodaje da ,da se nazove društveni fakt totalan ne znači da se govori samo za to da je sve što je nadgledano dio opservacije, već prije svega, da u jednoj nauci u kojoj onaj što nadgleda je od iste prirode kao i njegov
} 
No, što je tačno refleksivnost? Burdje daje mnogo definicija ovog pojma kroz svoja djela i najbolje je da započnemo sa nekom od tih njegovih definicija. Refleksivnost podrazumjeva „objektiviziranje transcendentalnog nesvjesnog koje subjekt što spoznaje, bez da zna, investira u akte spoznaje“, (2004;78) ili na drugom mjestu u njegovom djelu, „da se praktikuje refleksivnost znači da se ispituje privilegija subjekta koji spoznaje, arbitrarno isključen od procesa objektivizacije... i preko toga da se dobije jasniju svjesnost i veće vladanje ograničenja koje može da bude prepreka naučnom subjektu..." (Bourdieu 2000:119-120) Kao što možemo vidjeti, ovdje se drži za istinito produžavanje kantijanskog kritičkog projekta par excellence, ali posmatrano kroz kontekst ne čistih transcendentalnih a priori formi van vremena, prostora, kulture, društva i jezika, već kao sociotranscendentalni preduslovi spoznaje, sa posebnim akcentom predikata socio. $(2004 ; 79)$ Društveni temelji su ključni u opredjeljivanju kategorija i istraživača i objekta istraživanja kao istraživački problem. Jedna poznata teoretičarka prelijepo sumira značenje ovog koncepta kada kaže da je refleksivnost „,..pokretno predstavljanje objekta uz konstantu (re)formulacija/ekspresija njegove upotrebe i značenja“, i kasnije dodaje da „kao naučna metoda Burdjeovo razumjevanje refleksivnosti može da se definira kao kritički, epistemološki proces, što podrazumjeva objektifikaciju same konceptualizacije procesa naučne objektivizacije. Ukratko, refleksija se ne treba raditi i istraživati jedino na objekat proučavanja, već i sama elaboracija objekta istraživanja i uslova njegove elaboracije“. (Deer 2008,199-200)

Po Burdjeu, preko procesa refleksivnosti samom istraživaču se otkrivaju i popunjavaju slijepa mjesta njegovog naučnog pogleda - to što je sakriveno i što bježi od pogleda ne samo naučniku kao habitusu već i nauci kao autonomnom polju. „Da bi izašlo na svjetlost dana to što je par excellence sakriveno“, piše Burdje, „to što bježi od pogleda nauci, zato što je sakriveno od samog naučnikovog pogleda, odnosno transcendentalno nesvjesno, mora da se istorizira subjekt koji istorizira, da se objektivizira subjekt objektivizacije, odnosno ono istorijski transcendentalno -

objekat proučavanja, onaj što posmatra/nadgleda je dio vlastite opservacije." (Levi Straus 1987:28-29) 
objektivizacija koja je preduslov pristupanja nauke samosvjesnosti, ili, drugim riječima, znanju temeljenom na vlastitoj istorijskoj presupoziciji“. (2004:86) Preko refleksije produžava se kantijanska kritička tradicija koja istovremeno postavlja preduslove, mogućnosti i granice svakog naučnog saznanja i samim tim naučniku omogućava veću slobodu i njegovu veću samosvijest za granice vlastitog habitusa i polja u kojem djeluje. Za razliku od fenomenologije - najvažnijeg polemičkog neprijatelja Burdjea, zajedno sa strukturalizmom - i sa cijelim čistim kantijanskim projektom, refleksivni projekt Burdjea podrazumjeva i pogled okrenut van, prema polju u kojem agent (u ovom slučaju istraživač), djeluje i razmišlja. Zbog toga, kao što naglašava više puta, polje istovremeno i stvara agenta i stvoreno je od njega, većinom preko agentove prakse, odnosno njegovog djelovanja. (2000:120)

Burdje smatra da se na ovaj način kantijanski kritički projekt dodatno radikalizira: proces refleksivnosti ne samo što nije kontradiktoran sa kantijanskim projektom (pa čak i možemo da kažemo sa cjelim prosvjetiteljskim projektom Aufklärung-a), već on ga gleda kao logično produženje kantijanske kritičke filozofije. Ključna razlika je u tome što refleksija kod Burdjea podrazumjeva gledanje i u polju mogućnosti istorijskih mogućnosti -za konstrukciju tog subjekta koji je sada stavljen u poziciju da spoznaje i da proizvodi znanje. (2000:120) Ali kako se tačno praktikuje refleksija, sada kada imamo jasniju sliku za to što ona predstavlja? Burdje konstatuje da refleksija, odnosno objektivizacija istraživačkog subjekta podrazumjeva dvojnu istorizaciju - simultanu istorizaciju subjekta i objekta - koja treba da se realizuje na tri nivoa:

1. Da se objektivizira pozicija subjekta koji objektivizira u cijelom društvenom prostoru, da se odredi njegova originalna pozicija i trajektorija, njegova pripadnost društvenim ili religioznim grupama, itd.; 2. Da se objektivizira njegova pozicija na polju specijalista, pozicija njegove discipline i njena veza sa drugim naukama, ritualima i cenzurom, specifični habitus i odnos i cijeli skup kolektivnih presupozicija njegove nauke; 3 . Objektivizacija svega što pripada sholastičkom univerzumu, „nezainteresiranog“ pogleda na svijet. (2004:94) Ovo tročlano opredjeljenje neophodno nas vodi prema opredjeljivanju tri konkretna pojma: polje, habitus $i$ sholastički univerzum - pojmovi koji su neraskidivo povezani sa 
refleksijom posmatranom u najopštijem okviru i konkretno sa refleksijom naučnika i naučnog polja.

\section{HABITUS NAUČNIKA U POLJU NAUKE}

Burdje mnogo puta beskompromisno potencira da naučnik/istraživač, kao i svi drugi agenti u društvenom prostoru, pripada određenom polju, u ovom slučaju polju nauke, sa svim svojim potpoljima (pojedinačne nauke i naučne discipline) i u saglasnosti sa tim podložan je objektivnim ograničenjima koja mu nameće polje. To u bukvalnom smislu znači da više ne možemo da govorimo za nauku, već za naučno polje ili polje nauke. Na taj način se diskreditira ideja za čistu nauku kao aktivnost potpuno izdvojenu i izoliranu (u pozitivnom smislu riječi) od ostatka društvene stvarnosti, i za naučnike kao bestjelesne umove nezainteresirane za ništa drugo osim istine. Ukoliko bi naučnici istinski bili ,nezainteresirani bestjelesni umovi“, van banalnosti svakodnevnice i praktičnog aspekta njihovih aktivnosti, oni ne bi bili različiti od Lapućana kakvim ih opisuje Džonatan Svift u trećem djelu Guliverovih putovanja. Sprotivno ovome, Burdje smatra da se naučnici spremaju, kao i svi drugi agenti koji naseljavaju određeno polje, da zadovolje/ispune određene interese generirane iz suodnosa između specifičnog polja kojeg su dio, i njihovog habitusa konstruiranog od specifičnih ograničenja tog polja. ${ }^{6} \mathrm{U}$ ovoj slici naučnici više nisu, „unificirana homogena grupa“ koja kolaborativno i harmonično stremi prema jednom zajedničkom cilju (cilj nauke, odnosno otkrivanje istine); kontra ovoj idealnoj i idealiziranoj situaciji, Burdje govori o stanju rata, borbe za vlast i dominaciju. (2004:45)

\footnotetext{
${ }^{6} \mathrm{Za}$ Burdjea interes je uvijek istorijski determiniran i suštinski povezan sa poljem; ne postoji interes u generalnom smislu riječi, već uvijek konkretan interes determiniran od polja. „Daleko od toga da je neki vid antropološke, prirodne pridobivke, interes u svojoj istorijskoj specifičnosti arbitražna je institucija. Ne postoji interes, već interesi, varijabilni sa vremenom i prostorom, takoreći beskonačno: ima isto toliko interesa koliko ima polja." Sa pojavom novog specifičnog polja, dodaje Burdje, pojavljuje se i specijaliziran interes. (Bourdieu 1994:87)
} 
Iz ovog razloga možemo govoriti o dvije forme determinacije: $s$ jedne strane determinacija agenta, njegova trajektorija, odnosno karijera, a s druge strane, determinacija polja, objektivni prostor i strukturni efekti koji djeluju na agenta. „Polje posjeduje potencijale“, bilježi Burdje i „vjerovatnu budućnost, koju habitus prilagođen polju može da predvidi“. (2004:60) Ono što je možda ključno kada se bavimo naukom jeste da se ne rukovodimo određenim metodama, a ni pravila ne slijedimo svjesno u najvećem djelu vremena, već se prepuštamo praktičnoj mudrosti ili vještini koja je u nama otjelotvorena preko habitusa. Drugo ime za habitus je „osjećaj za igru“ (feel of the game), koji stičemo preko prolongiranog iskustva u naučnim igrama, odnosno preko djelovanja u polju. Nauka, posmatrana sa aspekta agenata u praksi (ne ex post facto, već kao modus operandi) više je kao zanat ili umjeće. „Naučnik je otjelotvorenje naučnog polja“, konstatira Burdje, „stvarni princip naučnih praksi je u najvećem djelu sistem nesvjesnih, prenosljivih, generativnih dispozicija, koje imaju tendenciju da generaliziraju samu sebe“. (2004:40-41). Habitus, dodaje Burdje, može da zauzme specifične forme u zavisnosti od specijalnosti agenta koji je u ovom slučaju naučnik. ${ }^{7}$

Da bi jedan agent mogao da uđe u polje koje se izborilo za svoju autonomnost u granicama širokog polja društvenog prostora, ${ }^{8}$ mora da se ispuni više kriterija. Prvo i osnovno, agent mora da posjeduje kompetencije, ali ne u apstraktno-naučnom smislu (čisto znanje), već kao otjelotvoren habitus i osjećaj za igru, ili drugim riječima, da se odnosi kao naučnik, filozof ili umjetnik, u zavisnosti od polja u kojim je učesnik (ovo je razlog zašto su određeni naučnici postali izvor mnogih interesantnih i konfuznih anegdota koje su definitivno proizvod nepodudaranja habitusa agenta i polja

\footnotetext{
${ }^{7}$ U Logici prakse, habitus je definisan kao sistem „trajnih, pokretnih dispozicija, strukturiranih struktura predisponiranih da funkcioniraju kao strukturirajuće strukture, odnosno kao principi koji generiraju i organizuju prakse i predstave...”(Bourdieu 1990:53)

${ }^{8}$ Po Burdjeu, polje nauke je započelo bitku za svoju autonomnost sa Nikolom Kopernikom, a kompletiralo ju je sa stvaranjem Kraljevskog društva u Londonu. Svako polje mora da se izbori za svoju autonomiju zato što autonomnost „nije pridobivka, već istorijsko osvajanje, koje treba od početka ponovo da se osvaja." (2004:47)
} 
specijalnosti; agenti kao Ludvig Vitgenštajn, koji su ušli bez odgovarajućeg osjećaja za igru na neka mnogo prestižna i institucionalizirana naučna polja, kao Kembridž početkom dvadesetog vijeka). Burdje govori, ,ne samo o znanju, već o odnosu prema znanju“. Naravno da agent mora da vjeruje da igra u polju postoji i da je dovoljno važna - Burdje naziva tu vjeru illusio, odnosno „podčinjavanje imperativu nezainteresirane zainteresiranosti“. (2000:102)

Ta nezainteresiranost je nešto što agenti ne posjeduju (nije urođena niti je jedinstveno proizvod talenta), već nešto što se uči. (2004:51-55) „Na svakom polju korespondira fundamentalna gledna tačka svjeta, koja kreira vlastiti objekt”, piše Burdje. To je jednostavno tako, ,iz razloga, što svako polje, kao forma života, jeste mjesto jezične igre, koje daje pristup različitim aspektima stvarnosti”. „To, što prihvatamo kao zdravo za gotovo, u stvari je otjelotvorena i institucionalizirana vjera u polje, njegova gledna tačka i prioriteti, zato što je „svako polje institucionaliziranje pogleda na svijet i habitusa... specifičan modus razmišljanja (eidos), princip specifične konstrukcije stvarnosti, utemeljene na predrefleksivnoj vjeri u neospornu vrijednost instrumenata za konstrukciju i objekata konstruiranih na taj način (ethos)". (2000; 99-100)

Veliko ulaganje u svako polje - pa tako i u polje nauke - ono što pokreće agente $\mathrm{i}$ što ih motivira u njihovoj praksi jeste sticanje simboličkog kapitala. „Simbolički kapital je zbir opredeljenih osobina koje postoje u i kroz percepciju agenata koji posjeduju adekvatne kategorije percepcije... samo oni koji imaju dovoljno inkorporiran kulturni kapital mogu to da zabilježe i uvaže“. (2004:55) $)^{9}$ Specifični simbolički kapital u naučnom polju je naučni kapital, utemeljen na znanju i priznavanju (objavljene knjige, učestvovanje na konferencijama, dobijena priznanja i nagrade, objavljivanje tekstova u prestižnim časopisima, učestvovanje na projektima i slično). Simbolički kapital, po Burdjeu, djeluje kao kredit, čiji posjed u velikoj

\footnotetext{
${ }^{9}$ Simbolički kapital može, ali ne mora da se transformira u druge oblike kapitala, kao što je ekonomski kapital, na primjer. „Simbolički kapital se sliva prema simboličkom kapitalu“, uspostavljajući svoju dominaciju u polju prilikom akumulacije simboličkog kapitala, agent dobija ekonomske povoljnosti i ekonomski profit. (2004:56)
} 
količini omogućava simboličku moć nad poljem. (2004:34). „Težnja za akumulacijom znanja je neodvojiva od potrage za priznanjem i od želje da postanemo poznati..." ili drugim riječima, naučnici su isto tako agenti kao i svi drugi subjekti u društvu u potrazi za interesom; ono što $u$ njihovom slučaju pravi razliku jeste da je njihov interes proizvod autonomnog polja $\mathrm{u}$ kojem djeluju i samim tim je specifičan interes koji se ne može meriti i kritikovati u generalnim okvirima. (2000:110)

Glavna prepreka za posmatranje ove situacije - nauka kao polje (kao dio društvenog prostora), naučnik kao otjelotvoren habitus, nauka kao zanat, shvatanje interesa i simboličkog kapitala - jeste takozvana sholastička iluzija, sholastička gledna tačka ili sholastičko stanje. Sholastička iluzija je temelj illusio-a naučnog svijeta, zbir aktivnosti, percepcija i otjelotvorenog simboličkog kapitala koji ne dozvoljava da se sagleda nauka kao praksa, kao kombinovan proizvod objektivnih granica polja u okvirima društvenog prostora i habitusa agenta. Sholastički položaj izvodi praksu nauke ex post facto, kada naučni rad završi i sa tim, po Burdjeu, stvara fikciju o nauci kao potpuno autonomnoj, nedruštvenoj aktivnosti koja postoji jedino u umovima naučnika kao čista misao ili čista nauka. (2004:38-39) Sholastički svijet se definira u granici društvenog prostora nasuprot nižem svijetu ekonomije, kao nezainteresirana aktivnost utemeljena u negiranju ili u potiskavanju elementa produktivnog rada, koji je neosporno prisutan u njegovom funkcioniranju. (2000:19) Sa metodološkog gledišta, on nudi pozicije u kojima se agent osjeća ovlašten da percipira svijet kao predstavu, kao spektakl, da ga nadgleda od gore i izdaleka i da ga organizira kao da je stvoren jedino za naučnu spoznaju. (2000:21) Obrazac za ovu glednu tačku očigledno je idealni kantijanski subjekt, sa svojom univerzalnom percepcijom, „zasnovanom na tjelim svedenim na čist pogled“, a druga pozicija je ona za lektora za koga cijeli svijet izgleda kao jedan veliki tekst za čitanje. (Bourdieu 1994:94-103) Ova distinkcija se bazira na nizu binarnih opozicija između teorije i prakse, intelekta i tijela, ,apstraktnih čula“ vida i sluha $\mathrm{i}$ „tjelesnih čula“ ukusa, mirisa i dodira. Na kraju krajeva, riječ je o razlici između stvari koje čine kulturu i stvari koje nisu kultura, između svijeta simboličke produkcije i svijeta ekonomske produkcije, i na kraju, kao glavna organizirajuća podjela: između duha i tjela, kartezijanskih res cogitans i res extensa. (2000:22-23) 
Izvor sholastičkog pogleda na svijet, po Burdjeu, nalazi svoje korijene još kod Platona i zasniva se na sistemskom potiskivanju koncepta skholè, kao osnovni i najjači preduslov za razvoj čiste misli. To podrazumjeva da treba da se stave u zagrade potrebe konkretne situacije, ekonomsko ograničavanje i društvene nužnosti; ovde, po Burdjeu, distinkcija između igranja (paizein) i ozbiljnosti (spoudazein) nestaje i sama igra postaje ozbiljna (spoudaiôs paizein), na osnovu fraze koju Platon koristi da opiše filozofiju; i konačno, podrazumjeva poseban odnos prema slobodi, ili oslobođenom vremenu, koje je neophodan preduslov za egzistiranje sholastičke situacije i ujedno je obrazac za organizaciju sholastičkih institucija. (2000:12-14) Institucija ovog načina djelovanja i razmišljanja je univerzitet, a najveći grijeh (hibris sholastičke situacije), prema Burdjeu, jeste hibris bezgranične misli, a kao posebno podložnu, navodi filozofiju kao primjer Burdje navodi Kanta, Hegela i ranog Hajdegera. (2000:27) Refleksivnost, objektivizacija subjekta objektivizacije, nije nova borba za apsolutno znanje i za nove transcendentalne kategorije, već specifična forma epistemološke oprijeznosti, tako što Burdje vješto izbjegava zamku sholastičke, čiste nauke. (2004:89)

\section{ZAŠTO JE REFLEKSIVNOST NEOPHODNA U DRUŠTVENIM NAUKAMA}

Osim toga šta Burdje smatra da je teorija refleksivnosti u cjelini primjenljiva na naučnom polju, bez razlike da li je riječ o prirodnoj ili društvenoj nauci, on ipak potencira njenu važnost za nauke koje se bave sa proučavanjem društvene stvarnosti. Za ovo njegovo mišljenje postoje dva razloga. Prvi razlog jeste to što svi agenti, bez razlike u poglijedu njihove kompetencije, sposobnosti i znanja, intuitivno i nesvjesno vjeruju da su kompetentni sociolozi i psiholozi, da savršeno dobro poznaju i prepoznaju društvene procese i druge ljude koristeći se samo zdravim razumom. ${ }^{10}$

\footnotetext{
${ }^{10}$, ,Zdrav razum je skup/zbir samoevidentnosti koje su spodjeljene od svih i koji, unutar granica društvenog univerzuma, garantiraju primordijalan konsenzus o smislu svijeta. Oni su skup prećutkivano prihvaćenih površnosti koje daju mogućnost konfrontacije, dijaloga, takmičenje, pa čak i sam konflikt/sukob, i među kojim mora
} 
Istorija ima sličnu sudbinu, a „to leži u faktu što vjerujemo da smo već ispunjeni sa naukom: mi vjerujemo da u trenutku razumjemo, i jedna od prepreka je ova iluzija neposrednog razumjevanja. Jedan od načina da se presiječe ova iluzija je kada se ona objektivizira". (Bourdieu 2015:39)

Drugi razlog je činjenica da ,u društvenim naukama, realno je zaista eksterno i nezavisno od spoznaje, ali je i samo po sebi društvena konstrukcija, proizvod prošlih borbi, koje posmatrane iz ovog aspekta, ostaju vrlo bitne za nove borbe..." To postavlja društvene nauke u vrlo specifičan položaj, da postanu „društvena konstrukcija društvene konstrukcije“. Sam naučnik je dio stvarnosti koju opisuje i njegov naučni proizvod je dio borbe za proizvodnju društvene stvarnosti; on je dvostruko aktivan (umješan) i kao naučnik koji proučava i kao tvorac (stvaralac) (2004:88). Po Burdjeu, ovo se najviše odnosi na sociologiju, filozofiju, psihologiju, pedagogiju, antropologiju, lingvistiku i sve druge nauke i naučne discipline koje se bave deskripcijom i analizom društvene stvarnosti - nije važno da li to rade sa tačke gledišta subjekta (fenomenologija, psihologija) ili sa društvene tačke gledišta (strukturalizam, sociologija, antropologija). „U ovoj igri nema sudija koji u isto vrijeme nisu učesnici” (Bourdieu 2000:117) reći će Burdje, potencirajući da je svaki agent u polju simultano njegov učesnik potčinjen pravilima koja ga reguliraju, oblikuju, upućuju, discipliniraju i ograničavaju njegovo razmišljanje i djelovanje, i agent koji sa svakom svojom aktivnošću i govorom ponovo stvara polje kojeg je i sam dio. Naučno polje karakterizira preskriptivna deskripcija (2000:117), istovrjemeno stvaranje i konstruiranje predmeta posmatranja, opisivanja i analiziranja. Vrlo često, pod plaštom govorenja o stvarima onakve kakve jesu - odnosno, pod plaštom deskripcije stvarnosti - prelazi se na to kakve stvari treba da budu i na taj način dolazi do „prelaska“, to jest „klizanja“ od deskriptivnog prema normativnom. (2000:122)

„Svaka teorija, a sama riječ to govori, jeste određen program percepcije" i onaj naučni opis koji je najstrože ograničen na konstatacije, uvijek je izložen opasnosti da funkcionira kao preskripcija, sposoban da doprinosi sa svojim vlastitim verificiranjem da djeluje kao teorija pogodna

da postoji posebno rezervirano mjesto za principe klasifikacije, kao što su najvažnije opozicije koje strukturiraju percepciju svijeta." (2000:98) 
da ostvari ono što nagovještava. Dovoljno je da se zabilježi kako je bila shvatana društvena realnost određenih praksi, kao alkoholizam, abortus ili zabrana narkotika, kao mana, moralni pad, kulturna tradicija ili kompenzatorski odnos otpadnika jednog društva. (Bourdieu 1992:128129,136-137) Studija Bolest kao metafora Suzan Zontag pokazuje nam šta sve može da znače rak i tuberkuloza i kakvi sve moralni kvaliteti i nekvaliteti su bili pripisani bolesnim ljudima, često sa podrškom medicine, posebno pri liječenju tuberkuloze u XIX vijeku; a Levi-Stros, u knjizi Totemizam danas vešto analizira kako antropologija, upotrebljavajući koncept totemizma, kreira primitivnog Drugog kao okosnicu identiteta zapadnog, civilizovanog i prosvijetljenog čoveka. (Sontag 1978; Levi-Stros 1979)

Da ne bismo širili diskusiju, možemo da ukažemo na primjer koji Burdje daje za ovu preskriptivnu deskripciju društvenih nauka: primjer lingvistike (i srodnih oblasti koje se bave jezikom) i njenog odnosa prema službenom jeziku. Po Burdjeu, službeni jezik nije prirodno dat, već je proizvod određenih društvenih i istorijskih konteksta: zajednički posao lingvista, pisaca, radnika u obrazovanju, pravnika i još reda drugih činilaca. Sosirovski jezik, na primjer je ,istovrjemeno zakonodavan i komunikacijski kod“, a „univerzalnom subjekt govorniku“ Čomskog pripisane su „savršene jezičke kompetencije”, ili drugim riječima, kada lingvisti kao Sosir i Čomski etabliraju svoje teorije strukturalne lingvistike i generativne gramatike, oni istovremeno prave deskripciju i preskripciju, istovremeno opisuju i propisuju komunikacijski kod i idealni subjekt-govornik. (Bourdieu 1992: 22-23, 2151) Pitanje „kako pravilno govoriti“ istovrjemeno je i pitanje koje ima svoje političke i naučne korijene i istorija ovih naučnih preplitanja je kompleksna i značajna i ide čak i do tamo, gdje izgleda da je govor naučnika najautonomniji i izdvojen od donošenja sudova i vrjednovanja. ${ }^{11}$ Odličan primjer za to kako jedan naučnik koji radi u domenu društvenih nauka treba da praktikuje refleksivnost jeste sam Burdje; veoma je poučno poslednje

11 Za opširniju diskusiju po ovom pitanju, usmjeravam čitaoca prema prvom i drugom poglavlju Burdjeove knjige posvećenu jeziku, Što znači govoriti: ekonomija jezičkih razmjena. (1992:21-51, 51-83) 
poglavlje knjige Nauka za nauku i refleksivnost (2000:94-115) i posebna knjiga Pokušaj za samoanalizu. (Bourdieu 2008)

\section{ZAKLJUČAK}

U ovom radu, najprije smo pokazali tradiciju mišljenja iz koje Burdje izvlači pojam refleksivnosti; zatim smo definirali ovaj koncept kroz Burdjeove tekstove i kroz tekstove njegovih komentatora. U drugom djelu obratili smo pažnju na njegove teorije o naučnom polju, o habitusu naučnika i na kritiku koju Burdje upućuje sholastičkom univerzumu ili sholastičkoj situaciji. U poslednjem, trećem djelu, obratili smo posebnu pažnju na potrebu i značaj refleksivnosti u domenu društvenih nauka -kao specifika i posebnost njihovog polja i odnosa koje društvene nauke imaju prema znanju i prema objektu svog istraživačkog rada. Kao što smo naglasili još u uvodu ovog rada, refleksivnost zauzima centralno mjesto u kritičkom projektu Burdjea; svi oni koji imaju namjeru detaljno da se bave njegovim teorijama, a zatim da ih primjenjuju na svojim istraživačkim interesima, neophodno je, kao prvo, da ulože napor da shvate sve ono što Burdje govori o refleksivnosti, a da tek poslije to primjene u svom istraživačkom radu.

Uvođenjem koncepta refleksivnosti, Burdje pravi krupne promene u polju nauke. Najprije, radi se o istovremeno doslednom i radikalnom primenjivanju kantijanske kritike, odnosno preispitivanju svih individualnih i društvenih preduslova svakog naučnog saznanja. Nadalje, Burdje insistira da su naučnici - kao i svi agenti uključeni u društvenom prostoru determinirani logikom prakse; naučnici nisu bestjelesni umovi u potrazi za čistim znanjem, već zainteresirani činioci koji u potrazi za istinom teže i ka mnogo profanijim ciljevima i idealima: sticanju imena, prestižu, popularnosti, uticaju, dominaciji itd. On nikad ne poriče da je naučna praksa utemeljena u idealu potrage za istinom, već da pored toga naučnici streme i ka manje „čistim“ ciljevima, glavno okarakterizovanim kao ,akumulacija simboličkog kapitala“. Na kraju, Burdje nam obznanjuje jedno od svojih najvažnijih otkrića: da nauka u procesu opisivanja istraživačkog objekta, istovremeno njega i stvara. Na taj način, on nam potencira društvene i političke implikacije naučnog rada. Zahvaljujući pojmu refleksivnosti naučni radnici su prinuđeni da budu daleko kritičniji u svome radu i involviraniji u 
društvenim i političkim konsekvencijama svojih teorija. U svakom slučaju, refleksivnost nije anti-naučna aktivnost; Burdjeov cilj nije dekonstrukcija narativa nauke, već unapređivanje naučnog saznanja i naučne prakse. Samim tvrdoglavim insistiranjem na refleksivnosti, Burdje od nauke i od naučnika zahteva veću serioznost, političku i društvenu odgovornost $i$, najvažnije od svega, dosljedniju i iskreniju nauku.

\section{LITERATURA}

Bloor, D. (1983). Wittgenstein: A social theory of knowledge. London: The Macmillan Press.

Bourdieu, P. (1990). The Logic of Practice. Stanford: Stanford University Press.

Bourdieu, P. (1992). Što znači govoriti. Zagreb: Naprijed.

Bourdieu, P. (1994). In Other Words: Essays Towards a Reflexive Sociology. Stanford, California: Stanford University Press.

Bourdieu, P. (2000). Pascalian Meditations. Stanford: Stanford University Press.

Bourdieu, P. (2004). Science of Science and Reflexivity. Chicago: The University of Chicago Press.

Bourdieu, P. (2008). Sketch for a Self-Analysis. Chicago and London: The University of Chicago Press.

Bourdieu, P., Chartier. R., (2015). The Sociologist and The Historian. Cambridge: Polity Press.

Carnap, R. (1950). Empiricism, Semantics, and Ontology. Revue Internationale de Philosophie 4 (1950): 20-40. Reprinted in the Supplement to Meaning and Necessity: A Study in Semantics and Modal Logic, enlarged edition (University of Chicago Press, 1956).

Cassirer, E. (1951). The Philosophy of the Enlightment. New Jersey: Princeton University Press.

Deer, C. (2008). Reflexivity. In Grenfell. M. (ed.). Pierre Bourdieu: Key Concepts, 199-212. Durham: Acumen Publishing Limited.

Jenkins, R. (1992/2006). Pierre Bourdieu. London and New York: Routledge.

Kun, T. (1974). Struktura naučnih revolucija. Beograd: Nolit.

Levi-Stros, K. (1979). Totemizam danas. Beograd: Beogradski izdavačko-grafički zavod.

Levi-Strauss, C. (1987). Introduction to the Works of Marcel Mauss. London: Routledge \& Kegan and Paul.

Locke, J. (2014). An Essay Concerning Human Understanding. Hertfordshire: Wordsworth Classics of World Literature. 
Susan, S. (1978). Illness as Metaphor. New York: Farrar, Straus and Giroux.

Williams, R. (1965). The Long Revolution. London: Penguin Books.

Kant, I. (2012). Kritika čistoga uma. Beograd: Dereta. 
VEDRAN DIZDAREVIKJ

University "St. Cyril and Methodius" in Skopje, Faculty of Philology

"Blaze Koneski”, North Macedonia

\title{
AN ANALYSIS OF THE NOTION OF REFLEXIVITY IN PIERRE BOURDIEU'S THEORY
}

\begin{abstract}
In this paper, we are going to analyze one of the central notions in the theory of the French sociologist and anthropologist Pierre Bourdieu, the notion of reflexivity. In the first part, we are going to introduce this notion and the wide tradition of the Kantian philosophical project, and Bourdieu's specific reading of this project through the lenses of Emil Durkheim, Marcel Mauss, Rudolph Karnap, and Ludwig Wittgenstein. After that, through a close reading of some of Bourdieu's texts, in dialogue with the notes of his commentators, we are going to define the notion of reflexivity and its meaning. In the second part, we are going to observe the specific problem of the scientist in the field of science, his relation to the field, his habitus, and the particular problem of the scholastic situation - all of which are the main obstacles to the practice of reflexivity. In other words, we are going to practice reflexivity about the scientific calling and the scientific profession. Also, we are going to illustrate what it actually means to talk about the field of science, and not only about science in and of itself. In the third part, we are going to focus on the need for reflexivity in the domain of the social sciences, which are at the same time the product and the producer of social reality.
\end{abstract}

Keywords: reflexivity, Pierre Bourdieu, Immanuel Kant, field, field of science, habitus, scholastic illusion, social sciences 
